\title{
THE LITHUANIA BUFFER PROBLEM OF 1920
}

\author{
Česlovas Laurinavičius \\ (Lithuanian Institute of History)
}

\begin{abstract}
The Curzon Line is usually identified as the line of 8 December 1919 (similar to the current eastern border of Poland), running to the east of the Daugavpils-Vilnius-Hrodna railway. Typical historiographical texts state that the Soviet government decided to ignore the Curzon Line after 17 July 1920. But in fact, the Red Army crossed the Curzon Line on 13-14July and continued to occupy Vilna (Vilnius). Another inaccuracy follows from this one. The prevailing trend is to interpret the Lithuanian state's situation in 1920 as facing one of two ideology-based alternatives: either Lithuania is sovietised, or it is 'saved' by Poland, which occupies Vilnius and separates Lithuania from contact with Soviet Russia. But this raises a whole swathe of questions: how should the Lithuanians' struggle for Vilnius during the whole interwar period be viewed? How should assistance to Lithuanians from other countries, such as Germany, the USSR and Great Britain, be assessed? Finally, how should the return of Vilnius to Lithuania in 1939 be viewed? There is no answer to these questions, but the possibility of Lithuania as a buffer zone thanks to the Curzon Line, is ignored or hardly analysed at all. Using historical documents from Lithuania, Great Britain and Russia, and referring to the studies by Alfred Erich Senn, this article aims to find an answer to the question, why was the idea of Lithuania as a buffer state not realised in the summer of 1920? The idea that it would be more appropriate to call the line alongside Lithuania established at the Spa Conference 'the Lloyd George Line' is also discussed.
\end{abstract}

KEYWORDS: line of 8 December 1919; Spa Conference; Curzon Line; Vilnius; buffer state; David Lloyd George; Vladimir Lenin.

\section{The inspiration for the article}

Inaccuracies. It seems that when writing about the Curzon Line, only Alfred Erich Senn and Piotr Wandycz distinguished it from the temporary eastern border of Poland demarcated by the Entente's Supreme War Council on 8 December 1919. In addition, Senn indicated that Lithuania and Vilnius were meant to remain 
between these two lines, acting as a buffer between the military forces of the Soviet Union and the military forces of Poland. ${ }^{1}$ However, in other papers by historians from various countries about the international aspects of the Polish-Soviet war of 1920, the Curzon Line, as a rule, is identified with the line of 8 December 1919. ${ }^{2}$ The line is also mistakenly identified in official textbooks, encyclopaedias and on the Internet. On the English Wikipedia page under this heading, the text formally appears to be correct, but the map appearing beside the text is misleading. ${ }^{3}$ It could be that this is influenced by the discussion between the USSR and the Western Allies that developed during the Second World War over the planned restitution of Poland's borders, whereby the line of 8 December 1919 started to be called the Curzon Line. But this would mean that the Curzon Line is understood first of all as an ideological symbol, seeking to set Poland apart from the USSR, or Europe from what was 'not Europe'. In this context, the Lithuanian state is not mentioned at all, as if there was no room left for it to exist.

The actual situation. First of all, we shall present the formal version of the lines under discussion. The line of 8 December 1919 is very like the current eastern border of Poland. It began at Lake Vištytis, cutting off part of the former province of Suwalki, with Suwalki, Seiny and Punsk in the direction of Hrodna being

${ }^{1}$ A.E. Senn, 'Dèl pavadinimo 'Kerzono linija”, Lietuvos istorijos studijos 1 (1992), pp. 19-20; A.E. Senn, The Great Powers, Lithuania and the Vilnius Question 1920-1928 (Leiden, 1966), p. 30; P. Wandycz, 'The Polish Question', The Treaty of Versailles: A Reassessment After 75 Years. Eds. M. Boemece, G. Feldman, E. Glaser (Columbia UP, 1998), p. 332.

${ }^{2}$ J.R. Hooker, 'Lord Curzon and the "Curzon line", The Journal of Modern History, Vol. 30, No 2 (June 1958), pp. 131-136; P. Wandycz, Soviet-Polish Relations, 1917-1921 (Harvard UP, 1969), pp. 210-219; H.J. Elcock, 'Britain and the Russo-Polish Frontier, 1919-1921', The Historical Journal, Vol. 12, No 1 (1969), pp. 137-154; T. Fiddick, 'The 'Miracle of the Vistula': Soviet Policy versus Red Army Strategy', Journal of Modern History, Vol. 45, No 4 (1973), pp. 626-643; R. Debo, Survival and Consolidation. The Foreign Policy of Soviet Russia. 1918-1921 (London, 1992), pp. 223-23o; R. Ulman, AngloSoviet Relations, 1917-1921. Volume III. The Anglo-Soviet Accord (Princeton UP, 1972), pp. 135-19o; N. Davies, Orzet Biaty, Czerwona gwiazda. Wojna polsko-bolszewitska, 1919-1920 (Kraków, 2011), pp. 180, 205-21.

${ }^{3}$ Curzon Line: https://en.wikipedia.org/wiki/Curzon_Line; Die Curzon-Linie: https://de.wikipedia.org/wiki/Curzon-Linie (accessed: 2019-08-24). 
considered part of Poland, and then continued south towards the border of eastern Galicia. The Curzon Line, as it was interpreted in a note to Soviet Russia signed by the British foreign secretary Lord Curzon on 10 July 1920, ${ }^{4}$ was meant to go along the east side of the Daugavpils-Vilnius-Hrodna railway line, at a distance of 50 kilometres from it, and only at Hrodna was it meant to go along the line of 8 December 1919, also at a distance of 50 kilometres to the east.

What was the purpose of the Curzon Line? This line along the Daugavpils-Vilnius-Hrodna railway was the fundamental expression of the decision by the Entente countries taken at the Spa Conference on 10 December 1920. According to this decision, formulated mainly by David Lloyd George, the prime minister of Great Britain, Poland had to withdraw to its ethnographic territory, west of the line of 8 December 1919, and to hand Vilnius over to Lithuania. Lloyd George made the following reasoning: the Soviets, who were then conducting negotiations in Moscow with a Lithuanian delegation, had already announced that they would recognise Vilnius as belonging to Lithuania. ${ }^{5}$ Thus, there was a possibility that the Red Army would stop at Lithuanian-controlled Vilnius. (It was believed that, having stopped the Red Army's advance along the northwest front, which posed the greatest threat to Warsaw, the attacks in a southwest direction would also halt.) In this way, a kind of modus vivendi could be established between the warring countries, while a conference was planned for them in London, in order to find a resolution to the issue. ${ }^{6}$

However, this idea proved to be unsuccessful. Senn's works contain at least two explanations. According to one, the Poles were putting off returning Vilnius to the Lithuanians, and so, on 14 July, the Red Army pushed the Poles out of Vilnius. ${ }^{7}$ According to another version, the agreement signed in Moscow on 12 July 1920

${ }^{4}$ Документы внешней политики СССР (ДВП), т. 3 (Москва, 1959), p. 54.

${ }^{5}$ In the notes of 2 and 8 April 1920 from Commissar Georgy Chicherin to Kaunas, it was indicated that the Soviet government agreed to apply the ethnographic principle to determine the borders of Lithuania (ДВП, t. 2 [Москва, 1957], pp. 438-439).

${ }^{6}$ Documents on British Foreign Policy (DBFP), Vol. VIII, pp. 505, 524-530.

${ }^{7}$ A.E. Senn, 'Lithuania's fight for independence. The Polish evacuation of Vilnius, July 1920', Baltic Review, 13 (1961), pp. 32-39. 
between Lithuania and the Soviet Union had a secret clause, whereby the Red Army could occupy Polish-occupied Vilnius, and later (according to the Kaunas Convention of 6 August) transfer it to Lithuania. ${ }^{8}$ In other words, the agreement signed with Lithuania on 12 July allowed the Red Army to cross the Curzon Line. In one way or another, on 14 July, the Red Army gained control of the Vilnius-Hrodna railway line, and continued its advance on Poland. This apparently presumed the failure of the Spa resolution. But works by historians usually express the idea that the Soviets decided to cross the Curzon Line on 17 July, while the Red Army actually only crossed it at the end of July. In other words, the Spa resolution regarding Lithuania is more or less irrelevant.

A historiographic anomaly? What does all this mean? Is it a case of the typically offhand approach by major historiographies regarding 'small factors', or conversely, a tactical silence over an episode that was ultimately unfavourable towards little Lithuania? Perhaps it is a methodological problem, for which the science of history cannot find an answer?

Senn correctly related the Curzon Line to the Vilnius question. However, in explaining the continuation of the problem and its political aspects, in our opinion, he went down a path that led Lithuania's modern history to a blind-spot. He doubted the legal significance of the Soviet attribution of Vilnius to Lithuania: 'The terms of the [Lithuanian-Soviet Russian] treaty can be fully understood only against the background of the Polish-Russian war,' he wrote. ${ }^{9} \mathrm{He}$ also claimed that Poland, which took Vilnius from the Lithuanians in the autumn of 1920, saved the Lithuanian state from sovietisation. ${ }^{10}$ As such, it would follow that Vilnius was not really of any great significance to Lithuania.

But in this case, numerous questions arise. How then should we view the fact that, after the capture of Vilnius by the Polish general Lucjan Zeligowski (9 October 1920), the Lithuanians commenced with a national campaign: 'We shall not rest without

\footnotetext{
${ }^{8}$ A.E. Senn, The Great Powers, Lithuania and the Vilnius Question, p. 31.

${ }^{9}$ Ibid, p. 32.

${ }^{10}$ A.E. Senn, The Emergence of Modern Lithuania (New York, 1959), p. 195.
} 
Vilnius'? How should we view the constant encouragement shown by other countries, Germany, Soviet Russia and Great Britain, to Lithuanians in their struggle over Vilnius? How should we view the fact that after the Polish occupation of Vilnius, a new theatre of war formed in Eastern Europe? How could Lithuania recover Vilnius without Soviet Russia? And finally, how should we view the recovery of Vilnius after 1939 ?

It should be noted that in the current Lithuanian public discourse, the 'saving from sovietisation' version is especially popular. The Soviet period is 'cast aside' in the historical discourse as illegal and anti-social, regardless of the fact that in a methodological sense, after 1940 the continuum of Lithuanian history breaks off, while the 'saving from sovietisation' version practically brings Lithuanian history 'to an end' in the interwar period. As a result, from a historical perspective, the factually existing Lithuanian state is left 'hanging'.

So, it is worthwhile going back to the source: to sit down and make notes...

\section{The legal aspect}

Senn's reasoning was prompted by an observation made in the interwar years by the German author Bruno Griessinger (Die Vilniusfrage, Würzburg, 1930) that at the time of the signing of the treaty on 12 July,

'Neither the RSFSR nor the Lithuanians had physical possession of all the land mentioned therein. ${ }^{11}$ Furthermore, so far as the Lithuanian government was concerned, the boundary described in the treaty was never more than hypothetical. Lithuania never occupied the entire territory.12

The subtext of this context is as follows: the Soviet Russian government was virtual, not recognised by other states, so it had no right to the sovereignty that it allegedly bestowed upon Lithuania. In other words, Soviet-occupied Vilnius, which was later transferred to Lithuania, was merely the handover of illegal war

${ }^{11}$ Poland had occupied Vilnius from 19 April 1919 until 14 July 1920.

${ }^{12}$ A.E. Senn, The Great Powers, Lithuania and the Vilnius Question, p. 32. 
booty to a third party. This interpretation only served to strengthen the version about the 'secret agreement' between the Lithuanians and the Soviets.

Senn himself was open to alternative views. He said 'The RSFSR on December 22, 1918, had recognized the Lithuanian SSR, which had Vilnius as its capital. In the summer of 1919, as a result of military defeat, that government, having already merged with the Belorussian SSR (as Litbel), had been absorbed into the RSFSR. Thus, the Russians might again claim sovereignty over the land.' Eventually, 'Since the Bolsheviks were acting as the legal heirs of the Tsarist government, the treaty marked the legal birth of the Lithuanian state. ${ }^{13}$ But besides this, Senn also indicated another fact:

'On August 29, 1918, the Bolsheviks had renounced any and all rights to land obtained by the Tsarist Empire as a result of the partitions of Poland in the 18th century, and therefore, it was argued, they could not now claim to grant anyone else title to it.' ${ }^{14}$

This decree prompted Poland to see itself as the heir to the rights of the historic Polish-Lithuanian state as it was in 1772. ${ }^{15}$ That means, it was also the legitimate heir of Vilnius.

Looking over this bundle of facts and interpretations, Senn came to the conclusion that the Vilnius question could not be resolved only within the boundaries of legal formulae. The political context was also necessary. We shall return to politics later on, but first it would be worth discussing the mentioned legal aspects in more detail.

On claims to the borders of 1772. First, we should look at the meaning of the Soviet government decree of 29 August 1918. Legal theory would demand that we become familiar with the explanations given by the authors of the decree. But this would be a separate story, which we shall set aside for the future. In this case, the position of the Entente states is more important to us, which not only formed their policy after the First World War, but also became one of the most important sources of international

\footnotetext{
${ }^{13}$ Ibid.

${ }^{14}$ Ibid.

${ }^{15}$ J. Makowski, Kwestia litewska (Warszawa, 1929).
} 
law. There were various opinions among these states regarding valid grounds for Poland's claims to the 1772 borders. However, the main provision was the non-recognition of these claims. If France was more positive regarding these rights, then Great Britain and the United States denied them. As a result, on 8 December 1919, the Supreme War Council demarcated a temporary eastern border of Poland, which could be compared to its eastern border when it was part of the union with the Grand Duchy of Lithuania (GDL). ${ }^{16}$ Thus, there are grounds to state that the temporary Polish eastern border of 8 December 1919 was drawn along the western boundary of the former GDL. This meant that, according to the resolution by the Entente leaders, modern Poland did not automatically assume rights to the GDL. The road opened towards a new agreement, with Poland on one side, and Lithuania, Belarus and Ukraine on the other.

On the balance between secret and open diplomacy. The differing positions of the Entente countries regarding Poland's rights must have had some influence on the position of the Bolshevik government as well, even though the latter was, of course, guided by other motives. In one way or another, on 28 February 1920, the Soviet government appealed to Poland with an offer of peace, and allowed Poland to understand that it was inclined to give up a large portion of the Belarusian territories in Poland's favour, ${ }^{17}$ and thus also - of the Lithuania benefit. Jurgis Aleksa, the Lithuanian representative representing 'Kaunas-Lithuania', who was visiting Moscow at the time, was intent on working out the possibility of signing a truce between Lithuania and Soviet Russia. Lithuania's basic position was as follows: Russia had to accept the existence of Lithuania as an ethnographic territory with its capital in Vilnius; the treaty also had to define the border between Lithuania and

\footnotetext{
${ }^{16}$ See the following maps: L. Bron de la Tour, 1766; J. Senex, J. Harris, London, 1719; I. Tirion, J. Keiser, Ansderdam, 1733; J. Nieprecki, T. Mayer, Niuremberg, 1749; G. and D. Robert de Vaugondy, Paris, $175^{2}$ (Lietuva žemélapiuose (Vilnius, 2011), pp. 242, 249, 254, 259, 261).

${ }^{17}$ Заявление СНК правительству Польши и польскому народу, 28 января 1920 г. Известия o 20, 3 О January 1920 г.; Правда № 20, 3 О January 1920 г.; Historia dyplomacji Polskiej, T. IV (Warsawa, 1995), pp. 120-124.
} 
Russia. However, after consultations with the Soviet representatives, it became clear that a joint border with Lithuania was not part of Moscow's plans. Georgy Chicherin, the commissar for foreign affairs, expressed the idea that acknowledging Vilnius for Lithuania could only be done in secret. ${ }^{18}$

It was important for the Lithuanian government to know the attitude of the government of the United Kingdom on this issue. Since this was impossible to ascertain via diplomatic channels, Augustinas Voldemaras, the Lithuanian minister of foreign affairs, went to London himself. His talk with the foreign secretary's deputy Lord Charles Hardinge took place on 20 April, from which he managed to learn a few things. First of all, Hardinge explained that

'At these times secret treaties or secret clauses in treaties were strongly deprecated and were contrary to the view generally adopted of what is called "open diplomacy".'19 However, he then began to reason that, in order to reach an agreement with the Bolsheviks, the Baltic States should act so that 'Their best course would be to make the best terms they could in the best manner possible ...'

\section{And that}

'Even a secret treaty or exchange of notes would give the Lithuanian government a very strong claim, and should prevent the Bolsheviks from committing themselves too far to the Poles. ${ }^{20}$

This means that even before the Polish army's 'march on Kiev', the British Foreign Office envisaged its failure, and saw Lithuania's opportunity to stop the Red Army's eventual descent on Vilnius (?!). Either way, after his conversation with Hardinge, Voldemaras telegraphed Kaunas: 'The English suggest accepting the Soviets' secret proposals. Content is more important than form. ${ }^{21}$

London's favourable position in terms of the negotiations with the Soviets served as encouragement for Lithuania to send a delegation to Moscow. Meanwhile, Moscow had already spotted the

${ }^{18}$ Telegram from Jurgis Aleksa dated 7 March 1920 to Kaunas. Lithuanian Central State Archives (LCVA), col. 383, inv. 7, f. 76, p. 57 .

${ }^{19}$ Note dated 27 April 1920 from Curzon to the envoy in Warsaw, H. Rumbolt, about Hardinge's talk with Voldemaras. DBFP, Vol. XI (London, 1961), pp. 305-306.

${ }^{20}$ Ibid.

${ }^{21}$ Telegram from A. Voldemaras to Kaunas, 22 April 1920. LCVA, col. 383, inv. 7, f. 77, p. 203 . 
connection between the arrival of the Lithuanian delegation and London's interest in the no longer veiled intentions to recognise Vilnius for Lithuania. These related interests were important in a diplomatic, political and legal sense. It means that the Lithuanian-Soviet Russian treaty was not a bilateral agreement, but had elements of an international structure, with the participation of Britain and the Baltic States on one side, and Soviet Russia on the other. Eventually, other countries became involved as well.

The so-called secret Lithuanian-Soviet agreement was not secret at all: the appendix to Article 2 of the peace of 12 July 1920 was published in the Soviet press press at the time, and its basic content was also presented to the Lithuanian parliament when the treaty was being ratified. ${ }^{22}$ Only later was its publication in Lithuania somewhat restricted, probably in fear of propagandist accusations against Lithuania for its 'union with the Bolsheviks'.

On the concept of the self-determination of nations. In a legal sense, it is important to know the principles behind a legal act. As we know, the principle of the self-determination of nations was probably the most popular principle after the First World War. But once it started being applied, differences in its interpretation immediately started to arise. Poland, in its discussions with Lithuania, operated in accordance with the liberal (or plebiscite) concept of the principle. Based on this, the claim was made that according to the treaty of 12 July 1920, Lithuania had been granted an area inhabited by 684,00o Poles and only 109,00o Lithuanians. ${ }^{23}$ Meanwhile, in the peace negotiations between Lithuania and Soviet Russia, the ethnographic principle had been used to demarcate Lithuanian territory. That is, it was based on the fact of the self-determination of Lithuanians. Other things that were taken into consideration were not only the teritories where the Lithuanians lived, but also where they had lived, and 'the Lithuanian population had declined due to unfavourable historical circumstances' (they meant the significant assimilation

${ }^{22}$ Правда 18 о7 1920, No 157; Speech by the Minister of Foreign Affairs Dr J. Purickis to the Constituent Seimas on 6 August. Lietuva No 168, 10 o8 1920; DBFP, Vol. III (London, 1949), p. 403.

${ }^{23}$ P. Lossowski, Konflikt polsko-litewski 1918-1920 (Warszawa, 1996), p. 116. 
of Lithuanians over the course of history). At the same time, the population, emerged by colonisation and assimilation, should not be looked as priority. The question arose: did this method not contradict the principles of Enlightenment and progress? Unfortunately, as far as we know, until now the literature of legal and political science avoids giving an answer to how the relationship between the plebiscite and ethnographic principles should be assessed. Historic material presents a whole mass of documents, explaining that these principles were in most cases just instruments in the formation of political decisions.

Let us take, for example, the material from the Spa Conference concerning the issue of the Polish-Soviet war. It shows that Lloyd George initiated the design of the international constellation in Eastern Europe. Here are some typical statements testifying to his attitude towards the rights of Poland, Lithuania and Russia:

'Unfortunately, Poland had not been satisfied with her national boundaries ... She quarrelled with Lithuania, and seized Lithuanian territory ... [Lloyd George] certainly could not approach the British Parliament for assistance, unless he could say that it was ready to make a settlement with Lithuania, to take ethnography as the basis of its peace with Russia ... ${ }^{24}$

'[Lloyd George] produced an ethnographic map of Poland, and pointed out that the inter-Allied experts in Paris had advised him that Vilnius was far beyond the legitimate frontiers of Poland ... Vilnius was really a question between Lithuania and Russia, and not a Polish question at all. There might be a large Polish population in the town, but the surrounding country was in no way Polish.'25

When Lloyd George presented his version of a resolution, for Poland to transfer Vilnius to Lithuania, the Polish representative protested, and negotiations could have broken down altogether. At this point, Lord Curzon, the British foreign secretary, joined in the discussion:

'The object in view was to prevent Vilnius from falling into the hands of the Bolsheviks,' he said, and continued: 'The people who ought to defend it are the Lithuanians. Why should the Lithuanians not be allowed to occupy and defend the city, a line being drawn to the east of Vilnius beyond which they should

${ }^{24}$ Notes of a meeting held at the Spa Conference on 9 July 1920. DBFP, Vol. VIII, p. 505 .

${ }^{25}$ The British foreign secretary's notes of a conversation at the Spa Conference on 10 July 1920, ibid., p. $5^{27}$. 
not go? The Vilnius question would not be considered as settled by this, and all frontiers, including those of Vilnius, would subsequently be settled by the Supreme Council. The Lithuanians would hold it as a sort of "gauge". ${ }^{26}$

Curzon's explanation satisfied the Poles, and that was the extent of his contribution to the 'Curzon Line' concept. Then a note was sent to Moscow in Curzon's name, whereby it was indicated that the Red Army had to stop at a distance of 5 o kilometres from the Daugavpils-Vilnius-Hrodna railway, and also at points corresponding with the line of 8 December $1919 .{ }^{27}$ Curzon's telegram probably reached Moscow on 11 July, and on 12 July, the Lithuanian-Soviet Russian treaty was signed in Moscow, which, as has been mentioned, gave grounds for the Red Army to cross the Curzon Line at the railway mentioned. Interestingly, as late as 10 July, the Soviet leader Vladimir Lenin did not approve of signing the treaty with Lithuania. ${ }^{28}$ On the other hand, on 12-13 July, when sending a telegram to Commissar Josif Dzhugashvili-Stalin about Curzon's telegram, he did not mention the railway, referring only to the line of 8 December 1919 beginning at Hrodna. ${ }^{29}$ In this way, the history of 'the Curzon Line' as a potential legal factor seems to have reached its end.

Nevertheless, the political history of the line, which it would be more appropriate to call 'the Lloyd George Line', continued. ${ }^{30}$

\section{The political aspect}

As has already been mentioned, Senn related the Curzon Line to the eventual possibility of Lithuania serving as a buffer between Russia and Poland. This was an observation of prime importance in terms of the prospects of the Lithuanian state. But the concept of a buffer remained unexplained, which, to a large extent, negates the value of his observation.

${ }^{26}$ Ibid.

${ }^{27}$ ДВП, т. 3, p. 54. The Galicia question will not be discussed in this article.

${ }^{28}$ The Unknown Lenin. From the Secret Archive, ed. R. Pipes (New Haven, 1996), pp. $85^{-89}$.

${ }^{29}$ В.И. Ленин, Полное собрание сочинений, Т. 51 (Москва, 1978), pp. 237-238.

${ }^{30}$ Suggestions have been made to attribute the authorial rights of the 'Curzon Line' to Lloyd George's secretary Philip Kerr (R. Ulman, Anglo-Soviet Relations, 19171921, Vol. III, p. 155). 
Buffer variations. According to the material at hand, at least three versions of the buffer can be discerned. One should be connected to the mentioned intentions of Hardinge, according to which, having received nominal recognition of Vilnius from the Soviets, Lithuania would have the opportunity to protest about the Red Army storming into Poland over the Vilnius-Hrodna railway. According to this concept, Lithuania's rights to Vilnius would actually only be limited to the context of the Soviet-Polish war. Curzon's suggestion at the Spa Conference further highlights Hardinge's intention: to hand Vilnius over to the Lithuanians, so that they could defend it from the Bolsheviks. In other words, priority was given in Vilnius to the Polish diaspora living there, while the Lithuanians were left with the task of being simple pawns. Even though it is unlikely that, when writing the agreement of 12 July 1920, neither Kaunas nor Moscow were aware of the details of the discussions at the Spa Conference, there is no doubt that this version would have been (and was) rejected by both Kaunas and Moscow.

Another version is that, according to the logic as explained by Lloyd George at the Spa Conference, the Lithuanians should take Vilnius and secure the right to establish their rule there at the London conference, with the support of the Soviets. This version is purely hypothetical, but it does have major significance for Lithuania in defending its aspirations.

The third version is that the Soviets, who after occupying Vilnius transfer it to Lithuania in accordance with the convention signed in Kaunas on 6 August 1920, defend Lithuania's right to it in bilateral negotiations with Great Britain, resting on none other than the resolution reached at the Spa Conference. This version was the closest to being realised, as events actually did unfold in this direction. Readers are reminded that on occupying Vilnius, the Soviets established their regime there, and only agreed to hand the city over to Lithuania after the signing of the Kaunas Convention. ${ }^{31}$

${ }^{31}$ Protocols from the Lithuanian-Soviet negotiations over the implementation of the Kaunas Convention No 1-12 (8-26 August 1920). Архив внешней политики Российской Федервции (АВП), ф. 15о оп. 3, д. 23, пап. 4, л. 9-54. 


\section{Conditions for the Kaunas Convention}

1) London's decision to receive the delegation led by Leonid Kamenev at the end of July (the note dated 26 July from Curzon to Chicherin); $3^{2}$ this signalled the turn towards political negotiations between Great Britain and Soviet Russia. On the same day, 26 July, Colonel Richard Ward, the British representative in Lithuania, informed Curzon that Moscow had agreed to renew talks with Lithuania in Riga, and that '[the situation] in Vilnius appears to be somewhat improved and the Bolsheviks more tractable. 33

2) Encouragement for the Kaunas Convention could have been Lithuania's obligation not to join an anti-Soviet alliance. The Soviet diplomat Adolf Joffe informed Chicherin on 4 August that the Lithuanian representative at the conference in Bulduri (Latvia) had refused to join the anti-Soviet alliance. ${ }^{34}$ In addition, the ratification of the treaty of 12 July 1920 in the Lithuanian parliament (on 6 August) was accelerated.

The recommendations by Soviet diplomats to their leaders to 'eliminate the reasons for conflict with the Lithuanians'35 did have some effect. On 10 August, Joffe informed Chicherin: 'The Red Army's negotiations with the Lithuanians over the evacuation of Vilnius had an impact like a bomb exploding in Europe. ${ }^{36}$

Thus, all the factors mentioned testified to the trend to form a national Lithuanian state with Vilnius as a buffer between Soviet Russia on one side and Great Britain (the West) on the other.

After the Battle of Warsaw. The Red Army's defeat near Warsaw presupposed another trend. Of course, this defeat first of all meant that the Poles had defended their national sovereignty.

${ }^{32}$ ДВП, т. 3, с. 63.

${ }^{33}$ DBFP, Vol. III, pp. 402-4O3; Е.Ю. Сергеев, Большевики и англичане. СоветскоБританские отношения, с. 282; R. Ulman, Vol. III, pp. 187-20о.

${ }^{34}$ АВП, ф. 151, оп. 3, д. 5, пап. 2, л. 9.

${ }^{35}$ Correspondence between Chicherin, J. Ganecki and A. Joffe, 18 July-10 August 1920. АВП, ф. 151, оп. 3, д. 2, пап. 2, л. 20-25; д. 5, пап. 2, л. 4-8, 26.

${ }^{36}$ АВП. ф. 151, оп. 3, д. 6, пап. 2, л. 1-21. 
However, Poland's position regarding Lithuania demonstrated that it would not recognise the national state of Lithuania with Vilnius. The demands made by Polish diplomats at the end of August for Lithuania to abide by the line of 8 December 1919 actually veiled their intention to reconstruct the situation according to the Foch Line of 26 July 1919 (according to which Vilnius was attributed to Poland). ${ }^{37}$ On the other hand, the reaction of the Lithuanian diplomatic service can be viewed as inadequate, since it did not take the realities of the day into account: the formation of a new international structure, in which the national Lithuanian state had no place, was already under way..$^{8}$

On 4 August, Chicherin sent a telegram to Lithuania with the following information:

'If the Lithuanian government can guarantee the inviolability of its territories and is capable of resisting being captured by Poland, the Russian government is ready to promise to withdraw from Lithuanian territory (meaning the Red Army-occupied zone along the Hrodna-Lida-Molodechno railway)., ${ }^{39}$

Lithuania did not respond to this request. It appears that the prevailing opinion in Lithuania was that the Red Army would, without any specific agreement, and thanks only to the unfolding situation, act as a protection for Lithuania from Poland in the south. But on 22 September, the Polish army pushed the Red Army out of Hrodna and Lida, and Lithuania's situation took a turn for the worse.

On 28 September, Soviet Russia made a proposal to Lithuania to form a military union, or in other words, to make Lithuania a protectorate of Soviet Russia. The Lithuanian government delayed giving its response, even though some of the political elite were inclined to accept the Soviets' offer. ${ }^{40}$ This, of course, was deemed absolutely unsatisfactory by Poland. Its decision to cut Lithuania

${ }^{37}$ Sasiedzi wobec wojny 1920 roku, ed. J. Cisek (London, 199o), pp. 223-225.

${ }^{38}$ Č. Laurinavičius, 'Probleminiai Lietuvos ir Lenkijos santykių 1920 m. aspektai', in: Suvalku sutartis: faktai ir interpretacijos. Umowa Suwalkska: fakty i interpretacje, sud. Č. Laurinavičius (Vilnius, 2011), pp. 41-71, 253-287.

${ }^{39}$ ДВП, т. 3, p. 165.

${ }^{40}$ LCVA, col. 383, inv. 7, file 72, p. 23, 145; АВП ф. о151, оп. 1, пап.1, д. 1о, л. 46. 
off from Russia was backed by France. ${ }^{41}$ And Great Britain decided not to interfere. ${ }^{42}$ Not receiving a clear answer from Lithuania, and hearing the news of Britain's position, the Soviet government agreed with the demarcation line proposed by Poland in Riga on 5 October 1920, which cut Lithuania off from Russia. ${ }^{43}$ The idea of Lithuania as an internationally neutral buffer evaporated. After the Treaty of Riga, Lithuania found itself in the Polish sphere of influence. In occupying Vilnius, Poland did not take over the rest of Lithuania, for Western countries did not allow this. But Lithuania proper, known as a seasonal state or Litwa Kowenska, became a new hotbed for conflict.

\section{The scarecrow of sovietisation}

Everything that has been said above about variations of Lithuania as a buffer state can be erased by one thesis: the aim of the Soviets was to sovietise Lithuania. This is a thesis that historiography is so far helpless to contradict, as if it were a kind of religious dogma. Of course, there are factual grounds for it: a few days prior to the signing of the Lithuanian-Soviet treaty, while Lenin was analysing the text, he exclaimed: 'Lithuania must be sovietised.'44 When the Red Army occupied Vilnius, the former Litbel USSR government moved in, and started to engage in harsh agitation against the Lithuanian state. This was done regardless of the fact that the treaty with Lithuania had already been signed.

Of course, these are serious points; yet they are not enough to exhaust the whole sovietisation problem. Firstly, because the fact of sovietisation should not be identified with the denial of statehood, and less so with the end of the Lithuanian nation's cultural existence and progress. This type of identification cannot

${ }^{41}$ G. Urbaniak, 'French involvement in the Polish-Lithuanian dispute, 1918-1920', Journal of Baltic Studies, No 1 (1985), pp. 52-63.

${ }^{42}$ Announcement by the Lithuanian representative A. Tyszkewicz in London, 12 October 1920. LCVA, col. 383, inv. 7, file 74, p. 118.

${ }^{43}$ Announcement by the Lithuanian representative D. Zaunius in Riga, 4 November 1920. LCVA, col. 383 , inv. 7 , file 72 , pp. 47-48.

${ }^{44}$ Ленинский сборник, т. 38 (Москва, 1944), p. 320; The Unknown Lenin. From the Secret Archive, pp. 85-89. 
be put down to the activities of the socialist government headed by Vincas Mickevičius-Kapsukas in the first half of $1919 .{ }^{45}$

On the other hand, the issue of sovietisation demands a more detailed analysis of the processes related to it. This analysis would force us to reject the demonised image of the Soviet monolith, and not to ignore the so-called 'bureaucratic policy' model. Thus, it would be correct to distinguish the Comintern, with its Communist Party organisations, the Red Army as a military structure, the diplomatic service represented by the People's Commissariat of Foreign Affairs (PCFA), and the political leadership, the Central Committee of the All Union Communist Party (Bolshevik) and the Politburo. The figure of Lenin stood over and above all this structure, who, as has been noted on more than one occasion, was known for his phenomenal duality in combining the rigours of ideology with the pragmatism of a statesman.

Generally speaking, it should come as no surprise that Lenin, as the guru of the Comintern, spoke in favour of Lithuania's sovietisation when the opportunity became quite realistic after the Red Army's successful attack. But this was not the only reason why Lenin could demand that 'Lithuania must be sovietised' at that particular time. There are grounds to believe that when writing his comments on the text of the treaty with Lithuania, he was still guided by the approach that Lithuania, and especially Vilnius, was in effect within the Polish sphere of influence. So it is quite likely that, having become embroiled in a war with Poland, and agreeing on the provision of seeing the latter sovietised, the Soviet political leadership had the same projection in mind for Lithuania as well.

It is worth paying attention to one detail. In their discourse, the Soviets tried to hide the jurisdictional aspect, probably because they saw the law as a bourgeois institution. For example, when the Lithuanians began to protest over the establishment of a revkom (Revolutionary Committee) in Vilnius, the Soviet representatives

45 Č. Laurinavičius, 'Once Again on the Soviet Statehood in Lithuania in 1918-1919', Lithuanian Historical Studies, Vol. 13, 2008 (Vilnius, 2010), pp. 179-19o; Č. Laurinavičius, 'On Political Terror during the Soviet Expansion into Lithuania, 1918-1919', Journal of Baltic Studies, Vol. 46, Issue 1 (2015), pp. 65-76. 
explained that 'wherever the Red Army goes, a revkom is established as well.' A similar theme is evident in Chicherin's letter to Lenin, presenting the text of the treaty with Lithuania: 'Once our occupation is in place, it will be necessary to have a local Soviet authority, and to create a Vilnius Revolutionary Committee. ${ }^{\prime 46}$ But when the Red Army marched into territories that were controlled by the Lithuanian government, revkoms were not established, and the Red Army forces soon withdrew. The Red Army also acted this way in the territories occupied by Poland that had earlier belonged to Germany. ${ }^{47} \mathrm{An}$ interesting circumstance is that as sovietisation did not expand into Lithuanian-controlled territories, the British did not consider the sovietisation that was being implemented in Vilnius as a direct threat to Lithuania proper..$^{48}$

Either way, sovietisation was the credo of the political leadership. But the PCFA, led by Chicherin, had another view. Ever since the beginning of the negotiations with Lithuania, Soviet diplomacy was basically oriented towards a similar treaty with Estonia (and Latvia and Finland), and envisaged a treaty with Lithuania as a state that had its own political system. They only avoided making a formal record of attributing Vilnius to Lithuania. During negotiations in Moscow, intense discussions arose over whether Lithuania would form a military union with Russia, and thereby become a protectorate of Russia, or whether it would remain a neutral buffer. ${ }^{49}$

In the meantime, the Red Army looked upon Poland as an enemy that simply had to be conquered, and the expression of the conquest had to be the sovietisation of Poland. The army's strategic interest dictated the necessity of taking over the Vilnius-Hrodna railway. This could happen if Lithuania agreed to form an operational union against Poland, but the Entente countries strictly forbade Lithuania to do this. That is why the Red Army's leaders planned to unilaterally occupy Vilnius and take control of the railway mentioned.

${ }^{46}$ The Unknown Lenin. From the Secret Archive, p. 87.

${ }^{47}$ R. Debo, Survival and Consolidation, pp. 301-309.

${ }^{48}$ LCVA, col. 383 , inv. 7, file 74, p. 24; DBFP, Vol. III, p. 403.

${ }^{49}$ М.С. Павлова, Литва в политике Варшавы и Москвы в 1918-1926 годах, pp. $33^{-} 34$. 
On 10 July, the Lithuanian delegation sent a telegraph from Moscow: 'Until the peace with Poland, we will not be allowed to take back those places where the Polish army now stands and which will be abandoned when they are pushed back [by the Soviets]. $5^{\circ}$ This telegram only goes to show that the Soviets still considered Vilnius as Poland's property, and that they did not plan its transfer to Lithuania any earlier than their own peace treaty with Poland.

But on 12 July, the Soviet leadership decided to sign the treaty with Lithuania. There is no doubt that this turnaround in Moscow happened after they received Curzon's note. As far as Lithuania was concerned, the note contained two important pieces of information for the Soviets. Firstly, it explained that the line separating the Soviets from Lithuania should run along the Daugavpils-Vilnius-Hrodna railway. From this, Moscow could have concluded that Vilnius had to be transferred to Lithuania at the Entente's decision. The second news was that the Entente possibly projected Lithuania as a state, but one isolated from Russian influence. By going ahead with the rushed signing of the treaty with Lithuania, Lenin tried to take over the initiative from the Entente. When the Red Army occupied Vilnius with the formal agreement of Lithuania, it was clear that the Entente's unilateral plan for Lithuania was neutralised. The question remained open as to how the Soviets would react to another important issue raised in Curzon's note: would the Red Army's campaign stop at the line of 8 December 1919, and would they agree to a multilateral resolution in London, or would they pursue another path? The Soviets' deliberations also appeared to depend on the position London would take: would it agree to conduct political negotiations with Moscow or not?

This period of ambiguity lasted for about half a month. The Litbel headquarters that were established in Vilnius during that period engaged in obvious anti-Lithuanian activities, while Soviet diplomats and soldiers avoided contact with Lithuania's representatives. On 17 July, Chicherin announced to Curzon that the Soviets were choosing to conduct bilateral negotiations with bordering states. ${ }^{51}$ On 26 July,

${ }^{50}$ Telegram from Moscow, 10 July 1920. LCVA, col. 383 , inv. 7, file 77, p. 112.

${ }^{51}$ ДВП, т. 3, pp. 47-51. Lithuanian diplomats also showed little enthusiasm to participate in a multilateral conference. 
Curzon gave the following answer: as the Soviets were agreeing to start negotiations with Poland, London would agree to allow a Soviet delegation to come and continue trade negotiations, and also to 'discuss preliminary conditions for a peace conference. $5^{2}$

At this time, the negotiations between Soviet and Lithuanian representatives were also revived. As has been mentioned, an agreement of major significance was reached in Kaunas on 6 August: Lithuania agreed to speed up the ratification of the treaty of 12 July 1920, thereby granting judicial guarantees that it would abide by Article 5 of the treaty: observation of a neutral status. The Soviets were obliged to leave Vilnius by 1 September, and the transfer process commenced quite quickly (quite conversely to the claims that the Soviets handed Vilnius over to Lithuania only after they had to withdraw from Poland). ${ }^{53}$ At the same time, the activities of Litbel were suspended. So it can be said that only after signing the Kaunas Convention did the Soviets start to treat Vilnius as an integral part of the Lithuanian state, and Lithuania itself as a potentially neutral state. The Red Army faced opposition in Vilnius from the Polish diaspora, and tensions between Poles and Jews also hung in the air. These circumstances had an impact on the issue of transferring Vilnius to the Lithuanians.

Meanwhile, the Red Army intensified its attack on Poland, with the aim of its sovietisation. This was seen as the only way of halting its expansion into the neighbouring kresy (lands). In other words, only Poland was threatened with sovietisation by force of the dagger, so to speak..$^{54}$ The threat of a socialist revolution that was present in all other European countries at the time was the problem of each state individually. The acknowledgement of this

${ }^{2}$ Ibid., p. 63.

${ }^{53}$ P. Łosowski, Konflikt polsko-litewski, pp. 131-133.

${ }^{54} \mathrm{~A}$ whole body of research by authors allows us to suggest that in the summer of 1920, Poland appealed to the Entente countries for assistance not with the aim of achieving peace, but that having secured their support, it could proceed to attack. See: T. Fiddick, 'The 'Miracle of the Vistula': Soviet Policy versus Red Army Strategy', Journal of Modern History, Vol. 45, No 4(1973), pp. 626-643; R.K. Debo, Survival and Consolidation; И.В. Михутина, Польско-советская война 1919-1920 г.2. (Москва, 1994); M.J. Carley, Silent Conflict. A Hidden History of Early Soviet-Western Relations (Toronto, 2014). 
reality would, at least at the academic level, lay the foundations for rejecting a priori accusations about Soviet Russia being a monster intent on sovietisation. At the same time, it becomes possible to reconsider the Soviet-British negotiations in London in the summer of 1920 .

There is another detail worth attention: Lenin agreed to appoint Leonid Kamenev to head the delegation sent to London for negotiations only on 12 July, even though he had hitherto been of the opinion that the negotiations in London should only deal with trade issues, and that the leader of this delegation should be Leonid Krasin. But the appointment of Kamenev meant that the Soviets now viewed the negotiations with the British as happening on a political level..$^{55}$ This means that, in terms of timing, Lenin's decision to shift discussions with the British to the political level, and his decision to sign the treaty with Lithuania, coincided. On the other hand, Curzon's note of 26 July meant that London also accepted that negotiations were shifting to the political level..$^{6}$

\section{The political science aspect}

It would make sense to analyse the possibility of Poland's conquest in this case not in the ideological but in the political science context. The point is that when Poland started its attack on the Soviet Union from the west, the army of General Pyotr Wrangel soon followed suit from Crimea towards Moscow. Objectively speaking, these were attacks that depended on each other, and were initiated mainly by Paris. As British-Soviet negotiations were already under way at the time in London, and London was trying to distance itself from Poland's and Wrangel's aims, whereas Paris was doing the opposite by constantly stepping up its support for Poland and Wrangel, the opportunity emerged for Red Moscow to engage in a great game. The main punch was to be thrown at Europe's most sensitive spot, Poland. If it were occupied, the Soviets would be one up against the Entente (primarily Paris; and

\footnotetext{
${ }^{55}$ И.В. Михутина, Польско-советская война 1919-1920 г.2., pp. 171-172. ${ }_{56}^{6}$ ДВП, т. 3, p. 63.
} 
after the withdrawal from Poland, not without certain conditions being met, of course, Wrangel would be dismissed). The logic of the association between the Poland and Wrangel factors is evident in numerous Soviet documents, beginning with Lenin's telegram to Stalin of 13 July, and Stalin's response that same day. ${ }^{57}$

It appears that London reconciled itself with this logic. Lloyd George's negotiations with Kamenev on 6 August are evidence of this, during which a set of conditions regarding Poland were coordinated. The essence of the conditions was that the Red Army would stop its advance if the opportunities for Poland to move in an easterly direction into a counterattack position were eliminated. Another provision was decided on by both sides: if Poland and France were to reject these conditions, Britain and Soviet Russia would be free to come to a bilateral agreement. ${ }^{8}$ As history shows, both Poland and France rejected these conditions. The Red Army could take Warsaw, while London and Moscow could engage in further talks on the division of power in Eastern Europe. ${ }^{59}$ In this context, at least in theory, there is a relatively realistic chance to see Lithuania as a neutral buffer state.

Negotiations between Lloyd George and Kamenev, 'Lenin's man in London', symbolised not just a discussion between two powers, but two value systems, each global in scale. ${ }^{60}$ At the time when the Red Army was approaching Warsaw, and Germany nurtured the hope that it could at least reduce the weight of the burden of Versailles, if not shake it off completely, France acknowledged Wrangel's government in Crimea, and denounced the Soviet treaties with the Baltic States (mostly due to Russia's rights to regression in terms of debts), and the United States declared that all the Soviet treaties, including those with Lithuania, were void.

${ }^{57}$ В. И. Ленин, Полное собрание сочинений, т. 51, pp. 237-238; Большевистское руководство. Переписка, 1912-1927. Сборник документов, сост. А. В. Квашонкин, О. В. Хлевнюк, Л. П. Кошелева, Л. А. Роговая (Москва, 1996), Док № 86.

${ }^{5}$ DBFP, Vol. VIII, pp. 681-708.

${ }^{59}$ The famous rumours about Kamenev's secret condition regarding 'arming labourers' and his gift of diamonds to the Daily Herald newspaper do not change anything. These circumstances became 'problematic' only after the Red Army had experienced its defeat at Warsaw.

${ }^{6 \circ}$ Л. Данилкин, Ленин (Москва, 2018), p. 315; R. Debo, Survival and Consolidation, p. 229. 


\section{Final conclusions}

The phenomenon of the Curzon, or more precisely 'the Lloyd George', Line should be considered as important, at least in Lithuania's history. Had the line not been mentioned in the note that Moscow received on 11 July 1920, who knows whether the Lithuanian-Soviet treaty of 12 July 1920 would have been signed? And even more so, would Vilnius have been attributed to Lithuania?

Nonetheless, it can be said that the line of 8 December 1919, the resolution of 10 July 1920 made at the Spa Conference, the Lithuanian-Soviet Russian treaty of 12 July 1920, and the Kaunas Convention of 6 August, are elements that created the conditions for Lithuania to become a state in a new international structure. In 1920, in the realm of London-Moscow interests, a whole group of neutral nation-states that were meant to perform a bridging function formed in the East European region, and this role was also intended for Lithuania. Of course, we cannot dismiss the fact that sooner or later a 'Mackinderian' question would have arisen: who would control the new region in Eastern Europe? At the same time, it is worth remembering that the formation of the region began much earlier, in a historical sense. It suffices to recall the beginning of the First World War, when the famous British historian Arnold Toynbee simply imperatively recommended that Russia create a system of national buffer states around itself. ${ }^{6}{ }^{6}$ And admittedly, both the pre-revolutionary and Soviet versions of Russia more or less followed that recommendation. But it would be difficult to assess the position of Britain itself in that process; that would be an altogether separate topic.

In one way or another, the structure of Eastern Europe in the summer of 1920 took on clear contours. Alas, that structure was dismantled in the autumn of 1920, when Poland's occupation of Vilnius cut Lithuania off from Russia. A 'barbed wire' system was put in place instead.

\footnotetext{
${ }^{61}$ A. Toynbee, Nationality and War (London, 1915), pp. 301-302, 339-358.
} 
Author Details

Česlovas Laurinavičius is a doctor of history, and senior research fellow at the Lithuanian Institute of History. Research area: history of diplomacy, geopolitics. Address: Lithuanian Institute of History, 5 Kražių St, Vilnius LT-o11o8, Lithuania E-mail: laurinaviciusc@gmail.com

\section{Bibliography}

Documents on British Foreign Policy. 1919-1939. Ser. 1. Vol. III, VIII (London, 1949-61).

The Unknown Lenin. From the Secret Archive. Ed. R. Pipes (New Haven, 1996).

BALKELIS, Tomas. Lemtingi metai. Lietuva 1914-1923 m. Karas, revoliucija ir tautos gimimas (Vilnius, 2019).

DAVIES, Norman. Orzet Biaty, Czerwona gwiazda. Wojna polsko-bolszewitska, 1919-1920 (Krakow, 2011).

DEBO, Richard K. Survival and Consolidation. The Foreign Policy of Soviet Russia. 1918-1921, (London, 1992).

ČEPĖNAS, Pranas. Naujujų laiku Lietuvos istorija. T. II (Vilnius, 1992).

ELCOCK, Howard J. 'Britain and the Russo-Polish Frontier, 1919-1921', The Historical Journal, Vol. 12, No 1 (1969), pp. 137-154.

FIDDICK, Thomas. 'The 'Miracle of the Vistula': Soviet Policy versus Red Army Strategy', Journal of Modern History, Vol. 45, No 4 (1973), pp. 626-643.

HOOKER, James R. 'Lord Curzon and the "Curzon line"', The Journal of Modern History, Vol. 30, No 2 (June 1958), pp. 131-136.

LOSSOWSKI, Piotr. Konflikt polsko-litewski 1918-1920 (Warszawa, 1996).

SENN, Alfred Erick. 'Dèl pavadinimo „Kerzono linija”, Lietuvos istorijos studijos, 1 (1992), pp. 19-20.

SENN, Alfred Erick. The Great Powers, Lithuania and the Vilnius Question 1920-1928 (Leiden, 1966).

SENN, Alfred Erick. 'Lithuania's fight for independence. The Polish evacuation of Vilnius, July 1920', Baltic Review, 13 (1961), pp. 32-39.

TOYNBEE, Arnold J. Nationality and War (London, 1915).

ULMAN, Richard H. Anglo-Soviet relations, 1917-1921. Vol. III. The Anglo-Soviet Accord (Princeton UP 1972).

URBANIAK, George. 'French involvement in the Polish-Lithuanian dispute, 1918-1920', Journal of Baltic Studies, 1 (1985), pp. 52-63.

WANDYCZ, Piotr. Soviet-Polish Relations, 1917-1921 (Cambridge, 1969). Данилкин, Лев. Ленин (Москва, 2018). 
Ленин Владимир Ильич. Полное собрание сочинений. Т. 51 (Москва, 1978).

Михутина, Ирина Васильевна. Польско - советская война 19191920 2.2. (Москва, 1994).

Павлова, Мария. Литва в политике Варшавы и Москвы в 1918-1926 годах (Москва, 2016).

Сергеев, Евгений. Большевики и англичане. Советско-Британские отношения, 1918-1924. От интервениии к признанию (Санкт-Петербург, 2019).

Большевистское руководство. Переписка, 1912-1927. Сборник документов, сост. А.В. Квашонкин, О.В. Хлевнюк, Л.П. Кошелева, Л.А. Роговая (Москва, 1996).

Документы внешней политики СССР. Т. 3 (Москва, 1959).

\section{GRĮŽTANT PRIE 1920 METŲ LIETUVOS-BUFERIO PROBLEMOS}

Santrauka

\section{ČESLOVAS LAURINAVIČIUS}

Kerzono linija paprastai tapatinama su 1919 m. gruodžio 8 d. linija (panašia ị dabartinę Lenkijos rytinę sieną). Kerzono linija èjo palei Daugpilio-Vilniaus-Gardino geležinkelio rytinę pusę. Remiantis tipiniais istoriografiniais tekstais, Sovietinė vyriausybė 1920 m. liepos 17 d. nusprendè nesilaikyti Kerzono linijos. Bet, faktiškai Raudonoji armija peržengė Kerzono liniją liepos 13-14 d. ir užėmė Vilnių. Iš šio netikslumo kyla kitas: dominuoja tendencija Lietuvos valstybę $1920 \mathrm{~m}$. situacijoje interpretuoti per ideologijos sąlygotos alternatyvos prizmę: arba Lietuva sovietizuojama, arba ją, „išgelbẻja“ Lenkija užimdama Vilnių ir atkirsdama nuo sąlyčio su Sovietų Rusija. Bet tokia alternatyva kelia virtinę klausimų: kaip vertinti lietuvių kovą dėl Vilniaus visą tarpukarį? Kaip vertinti kitų šalių - Vokietijos, SSRS, Didžiosios Britanijos - suteiktą pagalbą kovojusiems lietuviams? Pagaliau, kaip vertinti Vilniaus sugrąžinimą Lietuvai 1939 m.? İ šiuos klausimus atsakymo nẻra. O tebẻra ignoruojama arba menkai analizuojama Lietuvos-buferio galimybė $1920 \mathrm{~m}$.

Kerzono linija buvo fiksuota Didžiosios Britanijos užsienio reikalų sekretoriaus notoje Maskvai 1920 m. liepos 11 d. Toji linija èjo geležinkeliu Daugpilis-VilniusGardinas ir buvo Antantės šalių Spa konferencijos $1920 \mathrm{~m}$. liepos 10 d. sprendimo esminė išraiška. Pagal tą sprendimą, iš esmès suformuluotą Didžiosios Britanijos premjero Davido Lloydo George‘o (Deivido Loido Džordžo), Lenkija privalėjo atsitraukti ị savo etnografinę teritoriją - į vakarus nuo $1919 \mathrm{~m}$ gruodžio $8 \mathrm{~d}$. linijos - ir perduoti Vilnių Lietuvai. Lloydas George'as samprotavo šitaip: sovietai, kurie tuo metu Maskvoje vedė derybas su Lietuvos delegacija, jau buvo darę pareiškimus, kad pripažins Vilnių Lietuvai. Taigi buvo tam tikra tikimybė, jog ties lietuvių valdomu 
Vilniumi Raudonoji armija sustos. Sustojus raudonarmiečių puolimui Šiaurės-vakarų frontu, kuris Varšuvai kèlè didžiausią grèsmę, tikètina, būtų stabdomas puolimas ir pietvakarių kryptimi. Tokiu būdu tarp konfliktuojančių šalių galèjo susidaryti savotiškas modus vivendi.

Lietuvos, Didžiosios Britanijos bei Rusijos archyvų medžiaga leidžia teigti, kad Lietuvos nacionalinei valstybei įtvirtinti 1920 m. teigiamą postūmį davė Didžiosios Britanijos ir Sovietų Rusijos derybos (netiesioginis kontaktas tarp Britanijos premjero Davido Lloydo George'o ir sovietinio lyderio Vladimiro Uljanovo-Lenino). Spa konferencijos sprendimas, viena vertus, ir Lietuvos-Sovietų Rusijos derybos, kita vertus, ir tiesioginès britų-sovietu derybos $1920 \mathrm{~m}$. vasarą liudija, kad Lietuvos nacionalinei valstybei su Vilniumi (ir eventualiai Klaipėda) vėrèsi perspektyva tapti tarptautinio lygio neutralizuotu buferiu, išskiriančiu konfliktuojančias jẻgas, visų pirma Lenkiją ir Rusiją. Kitaip tariant, Lietuvai vėrėsi galimybė tapti neutralizuojančiu tiltu tarp Sovietų Rusijos ir Europos. Tokiame kontekste nebeliktų pagrindo absoliutinti sovietizacijos grèsmės Lietuvai.

Bet per Londono ir Maskvos kontaktą konstruojama tarptautinė struktūra Rytų Europoje griuvo, kai Lenkija po pergalès prieš Raudonają armiją užėmė Vilnių grasindama pajungti visą Lietuvą. O Rytų Europoje įsigalëjo „spygliuotos vielos“ barjeras. Vis dèlto prieš tai formuotos struktūros kontūrai išliko. Vienas tų kontūrų - Spa konferencijoje Loydo George‘o kelta Lietuvos su Vilniumi idejja, pripažinta ir Sovietų Rusijos. Tuo pagrindu straipsnyje siūloma Kerzono liniją vadinti Loido Džordžo linija. 